\title{
Analisis Berbagai Faktor Yang Dipertimbangkan Dalam Melakukan Segmentasi Pasar Berdasarkan Benefit Dan Preferensi Pada Perusahaan Asuransi di Malang
}

\author{
Boge Triatmanto ${ }^{1}$
}

\begin{abstract}
Objective of the research is to find out the considered factor for market segmentation at the insurance company in Malang based on benefit and preference approaches. Data analysis used factor analysis in order to find out any considered factors in performing market segmentation based on benefit and preference approaches. Result of the research shows five dimensions or factor, which are considered in performing market segmentation based on benefit and preference approaches of the customers at the insurance company in Malang. Those factors are is as fellow experiences of the company, product utility, varieties of the product, services and income. Result implication of the research for the insurance company in Malang shows that the segmentation should be directed to customers who pay more attention an reliability of the company and customers who look for utility of the insurance product as well as customers who get wage from side jobs in addition to monthly pay.

Key words : market segmentation, insurance company, factor analysis.
\end{abstract}

\section{PENDAHULUAN}

Sebelum era segmentasi dimulai, pemasar sering memasarkan produk dan jasanya dengan melakukan pemasaran massal (mass marketing). Pemasaran massal hanya bisa dilaksanakan bila konsumen mempunyai kesamaan keinginan, kebutuhan, hasrat, latar belakang pendidikan dan pengalaman. Pemsaran massal bisa dilakukan apabila pasar bersifat monopolistik, namun begitu hak monopoli di cabut dan persaingan baru muncul, maka perlahan-lahan konsumen akan mempunyai pilihan (preferensi). (Kasali; $1999: 41$ )

Selain pemasaran massal masih banyak pemasar yang langsung melakukan strategy positioning atau marketing mix, sementar ${ }^{2}$ a pasar sasarannya sendiri belum jelas, akibatnya hasil yang diharapkan menjadi tidak maksimal atau gagal bersaing karena kurang memiliki landasan yang kuat dalam memahami pasarnya. Seharusnya sebelum melakukan semua itu pemasar harus memeriksa segmennya, sudah tepatkah, pasar sasaran yang dipilih atau adakah perusahaan baru di pasar.

Ketika konsumen dan pasar berubah dengan cepat, monopoli dihapuskan, maka persaingan menjadi semakin tajam. Pemasaran massal, marketing mix, strategy

\footnotetext{
${ }^{1}$ Boge Triatmanto adalah Dosen Fakultas Ekonomi Universitas Merdeka Malang
} 
positioning (tanpa melalui tahapan segmentasi) menjadi sulit dipertahankan. Barang atau jasa yang berkualitas tinggi tidak lagi cukup dijadikan andalan. Perusahaan harus bisa memuaskan konsumen yang berbeda-beda yang dapat memilih berbagai macam barang dan jasa yang tersedia di pasar yang luas.

Berdasarkan hal tersebut, permasalahannya dapat dirumuskan sebagai berikut Bagaimanakah segmentasi nasabah asuransi di Malang berdasarkan pendekatan benefit dan preferensi. Tujuan penelitian ini adalah untuk mengetahui bagaimanakah segmentasi nasabah asuransi di Malang berdasarkan pendekatan benefit dan preferensi.

\section{Segmentasi}

Dalam menghadapi pasar yang semakin global, penting bagi perusahaan untuk memilah dan memilih pasar yang akan dimasuki. Proses memilih dan mamilah pasar bukanlah hal yang mudah, karena perusahaan harus mengidentifikasi terlebih dulu pasar yang akan dimasukinya. Segmentasi pasar dikembangkan untuk memilih salah satu pasar sasaran yang bisa diidentifikasi dari sudut pandang variabel-variabel yang relevan ( Sutisna $2003: 248$ )

Segmentasi didefinisikan sebagai “ kegiatan membagi-bagi pasar yang bersifat heterogen dari suatu produk ke dalam satuan-satuan pasar (segmen pasar) yang bersifat homogen” (Swastha, 1996 : 65). Sedangkan menurut Kotler (1998 : 352) segmentasi adalah " usaha pemisahan pasar pada kelompok-kelompok pembeli menurut jenis jenis produk tertentu dan yang memerlukan bauran pemasaran tersendiri”.

Berdasarkan definisi tersebut segmentasi pasar merupakan suatu falsafah yang berorientasi pada konsumen. Jadi, perusahaan yang berorientasi pada konsumen akan membagi pasarnya ke dalam segmen-segmen pasar tertentu dimana masing-masing segmen bersifat homogen. Homegenitas masing-masing segmen tersebut disebabkan oleh adanya perbedaan-perbedaan dalam kebiasaan membeli, cara penggunaan barang, kebutuhan pemakai, motif pembelian, tujuan pembelian dan sebagainya.

Menurut Kasali $(1999,138)$ terdapat lima syarat segmentasi yang baik antara lain Segmen yang dipilih cukup potensial dan dapat menjamin kontinuitas produksi sesuai dengan harga yang bersedia dibayar konsumen, daya beli cukup memadai dan kesediaan untuk membeli, harus dapat dibedakan dengan jelas dengan segmen-segmen lainnya, apakah sudah ada pesaing lain yang menguasai segmen itu, segmen harus dapat 
dijangkau baik secara fisik (distribusi) maupun non fisik (komunikasi-promosi), memiliki sumber daya manusia dan keterampilan SDM yang memadai.

Dalam melaksanakan segmentasi pasar menurut Lamb $(2001,299)$ langkah langkah yang harus ditempuh antara lain menyeleksi pasar atau kategori produk untuk dipelajari, memilih satu atau beberapa basis untuk melakukan segmentasi pasar, menyeleksi deskriptor segmentasi, membuat profil dan mengevaluasi segmen, menyeleksi pasar sasaran, merancang, menerapkan, dan mempertahankan bauran pemasaran yang tepat.

\section{Keuntungan Melakukan Segmentasi Pasar}

Lima keuntungan yang dapat diperoleh dengan melakukan segmentasi (Kasali 1998 ; 122) antara lain pertama, mendesain produk yang lebih responsif terhadap kebutuhan pasar. Mendesain produk yan gsesuai dengan kebutuhan atau keinginan segmen-segmen yang dituju. Kedua, menganalisis pasar. Segmentasi pasar membantu mendeteksi siapa yang menggerogoti pasar produk perusahaan. Ketiga, merumuskan peluang. Konsep segmentasi yang baik akan dapat ide untuk menemukan peluang. Keempat, menguasai posisi yang superior dan kompetitif. Perusahaan yang menguasai segmen pasar dengan baik adalah mereka yang paham betul konsumen dalam kelompok tersebut. Kelima, menentukan strstegi komunikasi yang efektif dan efisien. Perusahaan yang tahu siapa segmen pasar pasar produknya, akan tahu bagaimana berkomunikasi yang baik dengan segmen pasar tersebut.

Persyaratan segmentasi yang efektif, menurut Kotler (1995:336) antara lain ukuran, daya beli dan profil segmen yang dapat diukur, segmen cukup besar dan menguntungkan untuk dilayani. Suatu segmen harus merupakan nilai kelompok homogen terbesar yang memungkinkan dicari oleh program pemsaran yang dibuat khusus untuk mereka segmen dapat diajngkau dan dilayani secara efektif, segmensegmen dapat dipisahkan secara konseptual dan memberikan anggapan yang berbeda terhadap elemen-elemen dan program-program bauran pemasaran yang berbeda-beda, program-program efektif dapat dirumuskan untuk menarik dan melayani segmensegmen yang bersangkutan.

\section{Proses Segmentasi Pasar}

Dalam proses pemasaran, segmentasi tidak berdiri sendiri. Segmentasi merupakan satu kesatuan dengan targeting dan positioning, atau sering di kenal dengan singkatan 
STP (segmenting, targeting, positioning). Berikut gambaaran tentang tahapan utama dalam STP.

Gambar 1, Tahapan dalam Segmentasi Pasar, Seleksi Pasar dan Positioning

\begin{tabular}{|c|c|c|}
\hline $\begin{array}{l}\text { Market segmentation } \\
\text { 1. Identify bases for } \\
\text { segmenting the } \\
\text { market. } \\
\text { 2. Develop segment } \\
\text { profiles }\end{array}$ & $\begin{array}{l}\text { Market targeting } \\
\text { 1. } \begin{array}{l}\text { develop measure of } \\
\text { segment }\end{array} \\
\begin{array}{l}\text { atractiveness } \\
\text { 2. } \\
\text { select target } \\
\text { segment }\end{array}\end{array}$ & $\begin{array}{l}\text { Market positioning } \\
\text { 1. Develop positioning for } \\
\text { target segments. } \\
\text { 2. Develop a marketing } \\
\text { mix for each segment }\end{array}$ \\
\hline
\end{tabular}

Sumber : Kotler, (1998: 245)

Dalam gambar tersebut dijelaskan bahwa segmentasi yang dimaksud adalah proses membagi pasar ke dalam kelompok-kelompok yang lebih kecil, yang dibedakan berdasarkan kebutuhan, karakteristik, perilaku yang akhirnya menyediakan produk yang terpisah. Seleksi pasar (targeting) merupakan evaluasi terhadap segmen yang menonjol, kemudian melakukan evaluasi terhadap satu atau lebih segmen yang menonjol tersebut. Memposisikan pasar (positioning market) adalah membuat positioning yang kompetitif terhadap produk dan menciptakan sebuah marketing mix yang detail.

STP merupakan suatu rangkaian strageti pemasaran, dimana saegmentaasi adalah dasar bagi strageti selanjutnya yaitu targeting dan positioning. Segmentasi perlu dilakukan oleh perusahaan karena banyak manfaat atau benefit yang diperoleh bagi perusahaan. Segmentasi bermanfaat untuk meningkatkan posisi kompetisi perusahaan dan memberikan kebutuhan pelayanan yang lebih baik kepada konsumen, dapat meningkatkan penjualan, meningkatkan pangsa pasar, serta menaikkan reputasi perusahaan.

Ada berbagai macam cara untuk membentuk segmentasi. Wang, 1995 (dalam Kasali 1999 : 34) membaginya dalam dua kelompok yaitu pendekatan apriori dan pendekatan post hoc. Segmentasi apriori dilakukan sebelum data dikumpulkan dan menekankan kepada pendekatan berdasarkan atribut konsumen seperti usia, gender, kelas sosial, gaya hidup. Kasali (1999:35) menguraikan, bahwa segmentasi apriori dapat dibangun melalui pendekatan geografi, demografi, psikografi.

Proses segmentasi pasar membagi pasar yang heterogen ke dalam segmen-segmen homogen yang spesifik, segmentasi memungkinkan segmen-segmen yang teridentifikasi menjadi tertargetkan dengan jasa-jasa yang spesifik dan bauran pemasaran yang unik 
(Payne, 2001 : 84). Dengan demikian, segementasi mempunyai tujuan untuk memuaskan kebutuhan pelanggan secara lebih efektif, memastikan retensi pelanggan dan loyalitas pelanggan.

\section{Segmentasi Bagi Produk Asuransi}

Produk jasa seringkali tidak didiferensiasikan secara jelas. Segmentasi pasar memberikan peluang perolehan keunggulan kompetitif dalam pasar yang sangat kompetitif melalui diferensiasi. Pendekatan segmentasi pasar meliputi identifikasi manfaat (benefit) yang dicari oleh kelompok homogen yang berbeda yang memungkinkan sifat-sifat dan permintaan yang relevan ditentukan dan digunakan sebagai sumber diferensiasi (Payne, $2001: 86$ ).

Dalam dunia asuransi khususnya di Indonesia, segmentasi menjadi sangat penting dilakukan utamanya setelah persaingan semakin meningkat. Segmentasi berperan penting dan menjadi dasar bagi pengusaha asuransi untuk memposisikan produknya (product positioning) agar berbeda dengan pesaingnya. Segmentasi telah menjadi hal pertama dalam setiap perencanaan pemasaran yang sukses, serta menjadi strategi jangka panjang untuk pertumbuhan nasabah asuransi. Dalam rangka mencapai pertumbuhan tersebut pihak asuransi harus mengadaptasi segmentasi strategi yang tidak hanya berdasar kepada informasi demografi, tetapi juga kepada perilaku nasabah dahulu dan saat ini, serta belajar untuk merubah kriteria segmentasi agar sesuai dengan tujuan pemasaran.

Segmentasi dapat dibangun dengan pendekatan yang berbeda, disesuaikan dengan hubungan dan kebutuhan yang relevan. Di dunia asuransi pendekatan segmentasi disesuaikan dengan produk yang ada. Segmentasi yang dapat digunakan dalam dunia asuransi adalah berdasarkan pendekatan geografi, psikografi dan demografi.

Segmentasi dan positioning telah banyak digunakan para pengusaha asuransi, sebagai penerapan strategi, dengan melakukan pendekatan segmentasi berdasarkan manfaat (benefit) perusahaan asuransi dapat menemukan segmen yang tepat untuk bisnisnya, misalnya dari beberapa segmen yang ada ternyata ada segmen nasabah yang merasakan manfaat asuransi berdasarkan pelayanan dan waktu pembayaran premi yang luwes. Berasarkan segmen yang ditemukan ini asuransi dapat memposisikan sebagai perusahaan asuransi yang mengutmakan pelayanan dan keamanan dana nasabah. 
Dalam banyak kasus pendekatan segmentasi perilaku (behavior) adalah sebagai salah satu pendekatan yang direkomendasikan untuk membangun strategi positioning. Perilaku yang dimaksud adalah psikografi, kegunaan produk, manfaat, persepsi, preferensi, citra (image), marketing mix factor. Dari berbagai macam pendekatan perilaku persepsi dan preferensi mempunyai manfaat yang lebih untuk membangun strategy positioning.

Persepsi menekankan pada bagaimana observasi terhadap individu serta pemahaman terhadap merk, kategori produk, perusahaan, marketing issue lainnya. Pengetahuan tentang preferensi konsumen inisangat membantu perusahaan untuk menciptakan produk agar sesuai dengan segmen keinginan dan kebutuhan yang lebih spesifik.

Dalam rangka mencapai tujuan penelitian yang telah ditetapkan, hipotesis yang diajukan dalam penelitian ini adalah sebagai berikut : diduga bahwa faktor-faktor yang terdiri dari pengalaman perusahaan, manfaat produk, ragam produk, layanan dan pendapatan merupakan faktor-faktor yang perlu dipertimbangkan dalam melakukan segmentasi pasar bagi nasabah asuransi di Malang”

\section{METODE}

Jenis penelitian yang digunakan adalah penelitian penjelasan (explanatory) yaitu penelitian yang berusaha menjelaskan hubungan kausal yang terjadi antara variabelvariabel penelitian dan menguji hipotesis yang telah dirumuskan sebelumnya.

Penelitian ini dilakukan untuk mengidentifikasi berbagai faktor yang dipertimbangkan dalam melakukan segmentasi pasar produk asuransi berdasarkan pendekatan benefit dan preferensi. Sehingga dalam penelitian ini variabel-variabel ditentukan berdasarkan kuesioner yang dipakai sebagai instrumen dalam penelitian, sehingga dalam penelitian ini tidak menentukan variabel terikatnya mengingat penelitian ini ingin mengidentifikasi faktor yang dipertimbangkan dalam melakukan segmentasi pasar bagi produk asuransi. Kemudian faktor-faktor tersebut dikelompokkan menjadi lima faktor antara lain : pengalaman perusahaan, manfaat produk, ragam produk, layanan dan pendapatan.

Pengalaman Perusahaan $\left(\mathrm{X}_{1}\right)$, merupakan kemampuan perusahaan untuk meyakinkan nasabah berdasarkan pengalaman yang telah diperoleh selama bergelut di usaha asuransi. Indikator variabel ini adalah pernyataan responden dalam kuesioner 
tentang pertimbangan konsumen untuk nasabah berdasarkan pengalaman dan bonafiditas perusahaan.

Manfaat Produk $\left(\mathrm{X}_{2}\right)$, merupakan kemampuan produk perusahaan asuransi dalam memberikan manfaat yang diharapkan oleh konsumen di kemudian hari. Indikator variabel ini adalah pernyataan pilihan responden dalam kuesioner tentang manfaat yang diberikan produk asuransi yang diharapkan nasabah dimasa akan datang.

Ragam Produk $\left(\mathrm{X}_{3}\right)$, adalah banyaknya macam ragam pilihan produk yang ditawarkan oleh perusahaan sehingga mampu memberikan keleluasaan nasabah untuk memilih sesuai dengan kebutuhannya. Indikator variabel ini adalah pernyataan pilihan responden dalam kuesiner tentang banyaknya macam produk yang ditawarkan perusahaan serta fasilitas tambahan yang dirasakan nasabah.

Layanan $\left(\mathrm{X}_{4}\right)$, merupakan kemampuan perusahaan asuransi dalam memberikan pelayanan yang terbaik kepada konsumen, terutama dalam mempengaruhi konsumen untuk menjadi nasabah asuransi. Indikator variabel ini diukur berdasarkan pilihan pernyataan responden dalam kuesioner tentang pelayanan asuransi dan keluwesan waktu yang diberikan kepada nasabah untuk membuka polisnya.

Pendapatan Konsumen $\left(\mathrm{X}_{5}\right)$, adalah pendapatan konsumen dalam satu bulan yang dipakai sebagai pertimbangan konsumen untuk menjadi nasabah asuransi. Indikator variabel ini adalah pernyataan pilihan responden dalam kuesioner tentang pertimbangan besarnya pendapatan dalam satu bulan serta pendapatan lain-lain yang diterima selain gaji rutin yang diterimanya.

Populasi dalam penelitian ini adalah masyarakat Malang yang menggunakan jasa asuransi pada asuransi. Sedangkan teknik pengambilan sampel yang digunakan dalam penelitian ini adalah teknik simple random sampling. Teknik analisis data menggunakan Analisis faktor adalah suatu teknik untuk menganalisis tentang saling ketergantungan (interdependence) dari beberapa variabel.

\section{HASIL}

Dalam model penelitian ini menggunakan analisis faktor. Analisis ini dipakai untuk mengetahui faktor-faktor apa sajakah yang mempengaruhi segmentasi pasar produk asuransi pada asuransi di Malang. Dalam analisis ini jumlah butir kuesioner sebanyak 17 butir. Satu butir merupakan variabel dependen yaitu segmentasi pasar dan 16 butir lainnya merupakan representasi dari variabel independen yaitu segmentasi 
pasar berdasarkan benefit dan preferensi. Dalam mengidentifikasi variabel independen tersebut, dari 16 butir pertanyaan yang ada dalam kuesioner di kelompokkan menjadi lima faktor yang terdiri dari : pengalaman perusahaan $\left(\mathrm{F}_{1}\right)$, manfaat produk $\left(\mathrm{F}_{2}\right)$, ragam pilihan produk $\left(\mathrm{F}_{3}\right)$, layanan $\left(\mathrm{F}_{4}\right)$, pendapatan $\left(\mathrm{F}_{5}\right)$.

Ukuran kecukupan sampling, Pengujian awal interdependensi variabel-variabel adalah pengukuran terhadap kecukupan sampling (Measures of Sampling Adequacy atau MSA) melalui matriks korelasi anti-image pertama. Nilai MSA terdapat pada nilai-nilai yang ditunjukkan pada bagian diagonal matriks korelasi anti-image.

Tabel 1, Nilai MSA Masing-Masing Item

\begin{tabular}{|c|c|c|}
\hline \multirow{2}{*}{ Item } & \multicolumn{2}{|c|}{ MSA } \\
\cline { 2 - 3 } & Proses awal & Proses akhir \\
\hline $\mathrm{X}_{2}$ & 0,612 & 0,638 \\
$\mathrm{X}_{3}$ & 0,663 & 0,712 \\
$\mathrm{X}_{4}$ & 0,657 & 0,653 \\
$\mathrm{X}_{5}$ & 0,632 & 0,633 \\
$\mathrm{X}_{6}$ & 0,767 & 0,765 \\
$\mathrm{X}_{7}$ & 0,668 & 0,655 \\
$\mathrm{X}_{8}$ & 0,421 & - \\
$\mathrm{X}_{9}$ & 0,726 & 0,850 \\
$\mathrm{X}_{10}$ & 0,783 & 0,807 \\
$\mathrm{X}_{11}$ & 0,720 & 0,743 \\
$\mathrm{X}_{12}$ & 0,827 & 0,819 \\
$\mathrm{X}_{13}$ & 0,876 & 0,873 \\
$\mathrm{X}_{14}$ & 0,822 & 0,831 \\
$\mathrm{X}_{15}$ & 0,772 & 0,747 \\
$\mathrm{X}_{16}$ & 0,751 & 0,762 \\
$\mathrm{X}_{17}$ & 0,658 & 0,678 \\
\hline
\end{tabular}

Tabel diatas memberikan informasi bahwa nilai MSA masing-masing item pada proses awal diatas 0,5 berarti antar item saling interdependen. Kecuali $\mathrm{X}_{8}$ ( jarak atau kedekatan ) memiliki nilai MSA dibawah 0,5 yaitu 0,421 sehingga $\mathrm{X}_{8}$ disarankan untuk dikeluarkan dari analisis. Dengan dikeluarkannya $\mathrm{X}_{8}$ bukan berarti ke-15 item yang lainnya saling interdependen, untuk itu perlu dilakukan perhitungan ulang terhadap ke15 item. Sehingga pada proses terakhir dapat dilihat bahwa nilai MSA masing-masing item diatas 0,5. Dengan diperolehnya nilai MSA pada proses akhir, menunjukkan bahwa ke-15 item saling independen sehingga dapat dilakukan analisis selanjutnya.

Nilai KMO (Kaiser Meyer Olkin) merupakan sebuah indeks perbandingan jarak antara koefisien korelasi dengan koefisien korelasi parsialnya. Jika jumlah kuadrat 
koefisien korelasi parsial diantara seluruh pasangan variabel bernilai kecil dibandingkan dengan jumlah kuadrat koefisien korelasi, maka akan menghasilkan nilai KMO yang mendekati satu. Nilai KMO kecil menunjukkan bahwa analisis faktor bukan pilihan yang tepat, nilai KMO dianggap mencukupi jika lebih dari 0,5. Nilai KMO ini memiliki pengertian yang sama dengan nilai MSA, hanya nilai KMO bersifat umum sedang nilai MSA bersifat parsial (setiap item/variabel). Dalam analisis ini diperoleh nilai KMO sebesar 0,751. Sehingga bisa dinyatakan bahwa analisis faktor merupakan sebuah pilihan yang tepat karena nilai KMO lebih dari 0,5.

Bartlett test, cara ketiga untuk menguji interdependensi variabel adalah dengan melihat nilai Bartlett test. Nilai signifikan dari hasil Bartlett test mendekati nol menunjukkan bahwa matriks korelasi cocok untuk analisis faktor. Dalam analisis ini diperoleh hasil nilai Bartlett test of sphericity sebesar 768,964. Nilai ini menunjukkan bahwa nilai Bartlett test lebih besar dari tabel chi-square yaitu 105 dengan taraf signifikan 0,000 dibawah 0,05. Maka dapat disimpulkan bahwa $\mathrm{H}_{0}$ ditolak berarti matriks korelasi tidak sama dengan matriks identitas $\left(\mathrm{H}_{1}\right.$ diterima). Hal ini memberikan informasi bahwa variabel-variabel saling berkorelasi atau saling terkait. Melihat nilai signifikan dari Bartlett test mendekati nol maka dapat dinyatakan bahwa matriks korelasi cocok untuk analisis faktor.

Nilai detrminan ( $|\mathrm{R}|$ ) dari matriks korelasi, pengujian terakhir interdependensi variabel-variabel adalah dengan melihat nilai determinan dari matriks korelasi. Nilai determinan dari matriks korelasi yang elemen-elemennya menyerupai matriks identitas akan memiliki nilai determinan sebesar 1, artinya jika nilai determinan mendekati 1 berarti matriks korelasi menyerupai matriks identitas (antar variabel tidak saling terkait). Matriks identitas memiliki elemen pada diagonal bernilai 1 sedangkan lainnya bernilai 0. Maka untuk mengatakan bahwa matriks korelasi memiliki interdependensi, matriks korelasi harus memiliki nilai determinan 0. Nilai determinan matriks korelasi dari hasil analisis adalah 0,0004649. Nilai tersebut mendekati nol sehingga dapat dikatakan bahwa matriks korelasi memiliki tingkat saling keterkaitan yang mencukupi berarti antar item saling terikat.

\section{Ekstraksi Faktor}

Ekstraksi faktor adalah melakukan reduksi (pengurangan) dari sekumpulan variabel menjadi bagian yang lebih kecil dengan tidak menghilangkan karakteristik asal. 
Ekstraksi faktor dilakukan karena dalam analisis faktor tidak semua faktor diperlukan, ada sebagian faktor yang kemampuan menjelaskan keragaman total adalah rendah. Terdapat tiga metode untuk melakukan ekstraksi dalam analisis faktor.

Pertama, menentukan jumlah, pada ekstraksi ini analisis faktor dari 15 buah variabel akan menghasilkan 15 buah faktor yang bersifat kombinasi linier dari variabel asal dan memiliki kemampuan menjelaskan keragaman asal (variabel-variabel) yang tidak sama. Kemampuan faktor dalam menjelaskan keragaman asal ditunjukkan oleh eigen value. Karena kemampuan menjelaskan pada faktor yang terakhir semakin lemah (kecil) maka perlu pembatasan jumlah faktor yang digunakan, jumlah faktor ditentukan dengan alternatif : Eigen value $>1$, Persentase varian $>5 \%$, Persentase kumulatif $60 \%$. Pembatasan jumlah faktor tersebut mengakibatkan faktor untuk tahap analisis selanjutnya menggunakan 5 buah faktor pertama yang ke-5 nya memiliki eigen value > 1 .

Tabel 2, Penentuan Faktor Untuk Analisis Selanjutnya

\begin{tabular}{|c|c|c|c|}
\hline Faktor & Eigen value & $\begin{array}{c}\text { Prosentase } \\
\text { varian }(\%)\end{array}$ & $\begin{array}{c}\text { Prosentase } \\
\text { kumulatif }(\%)\end{array}$ \\
\hline 1 & 4,052 & 27,012 & 27,012 \\
2 & 2,633 & 17,553 & 44,564 \\
3 & 1,223 & 8,156 & 52,721 \\
4 & 1,108 & 7,385 & 60,105 \\
5 & 1.051 & 7,007 & 67,112 \\
\hline
\end{tabular}

Sumber : Data Primer yang diolah

Tabel diatas memberikan informasi bahwa dari 15 faktor hanya ada 5 faktor yang nilai eigennya lebih besar satu, dengan \% kumulatif $67,112 \%$.

Kedua, koefisien faktor (Factor Loading) sebelum rotasi, pada tahap ini didapatkan matriks faktor yang merupakan model awal sebelum dilakukan rotasi, koefisien (factor loading) yang signifikan $(\geq 0,5)$ pada setiap model faktor dapat dikatakan bisa mewakili faktor yang terbentuk. Bila pada ekstraksi faktor dihasilkan statistik awal maka pada tahap ini dihasilkan statistik akhir yang memuat nilai komunalitas. Jika terdapat faktor yang tidak mewakili satu itempun maka dipertimbangkan untuk dilakukan rotasi. Selengkapnya distribusi variabel yang signifikan terhadap faktor pada matriks faktor sebelum rotasi ada pada tabel berikut : 
Tabel 3, Distribusi Varabel Kepada Faktor Sebelum Rotasi

\begin{tabular}{|c|l|c|}
\hline Identifikasi faktor & \multicolumn{1}{|c|}{ Variabel } & Factor loading \\
\hline $\mathrm{F}_{1}$ & $\mathrm{X}_{9}$ (pengalaman asuransi) & 0,585 \\
(Pengalaman & $\mathrm{X}_{10}$ (promosi) & 0,692 \\
perusahaan) & $\mathrm{X}_{11}$ (bonafiditas) & 0,744 \\
& $\mathrm{X}_{12}$ (kecepatan pembayaran uang & 0,826 \\
& pertanggungan) & 0,571 \\
& $\mathrm{X}_{13}$ (ketepatan waktu) & 0,646 \\
& $\mathrm{X}_{14}$ (pengaruh personal selling) & 0,517 \\
& $\mathrm{X}_{15}$ (banyaknya macam produk) & 0,589 \\
\hline $\mathrm{F}_{2}$ & $\mathrm{X}_{16}$ (fasilitas tambahan) & 0,537 \\
(Manfaat) & $\mathrm{X}_{3}$ (pendapatan) & 0,796 \\
& $\mathrm{X}_{4}$ (tingkat pengembalian investasi) & 0,774 \\
& $\mathrm{X}_{5}$ (manfaat produk) & 0,750 \\
\hline $\mathrm{F}_{3}$ & $\mathrm{X}_{6}$ (pelayanan) & - \\
\hline Ragam Produk) & & 0,615 \\
\hline $\mathrm{F}_{4}$ & $\mathrm{X}_{2}$ (rasa aman) & 0,539 \\
\hline (Layanan) & $\mathrm{X}_{15}$ (banyaknya macam produk) & 0,682 \\
\hline $\mathrm{F}_{5}$ & $\mathrm{X}_{17}$ (hadiah pembelian) & \\
\hline (Pendapatan) & & \\
\hline
\end{tabular}

Tabel diatas memberikan informasi bahwa masing-masing variabel yang dikelompokkan ke dalam faktor memiliki factor loading lebih besar dari 0,5 sehingga dapat mewakili masing-masing faktor. Kecuali Faktor tiga $\left(\mathrm{F}_{3}\right)$ tidak mewakili satu item pun karena factor loading dari variabel-variabelnya lebih kecil dari 0,5 sehingga hasil kurang interpretable, untuk itu perlu dilakukan rotasi agar diperoleh hasil yang lebih sederhana.

Ketiga, rotasi faktor, dilakukan karena model awal yang diperoleh dari matriks faktor sebelum dilakukan rotasi, belum dapat menerangkan struktur data yang sederhana sehingga sulit untuk dapat diinterpretasikan. Dalam rotasi faktor ini factor loading dari masing-masing variabel dimaksimumkan sehingga diharapkan dapat mewakili faktor yang ada. Dengan dilakukannya rotasi faktor maka hasil dapat diinterpretasikan . Sebuah variabel dikatakan dapat diinterpretasikan atau mewakili satu faktor karena memiliki factor loading lebih besar dari 0,5. Dalam analisis ini setelah dilakukan rotasi faktor, maka dihasilkan model faktor yang jauh lebih sederhana daripada model faktor matriks sebelum dilakukan rotasi. 
Tabel 4, Distribusi Variabel Kepada Faktor Setelah Rotasi

\begin{tabular}{|c|l|c|}
\hline Identifikasi Faktor & \multicolumn{1}{|c|}{ Variabel } & $\begin{array}{c}\text { Factor } \\
\text { loading }\end{array}$ \\
\hline $\mathrm{F}_{1}$ & $\mathrm{X}_{9}$ (pengalaman asuransi) & 0,585 \\
(Pengalaman & $\mathrm{X}_{11}$ (bonafiditas) & 0,744 \\
perusahaan) & $\mathrm{X}_{12}$ (kecepatan pembayaran uang & 0,826 \\
& klaim asuransi) & \\
& $\mathrm{X}_{14}$ (pengaruh personal selling) & 0,646 \\
& $\mathrm{X}_{13}$ (ketepatan waktu pembayaran) & 0,571 \\
\hline $\mathrm{F}_{2}$ & $\mathrm{X}_{4}$ (tingkat pengembalian investasi) & 0,796 \\
$($ Manfaat) & $\mathrm{X}_{5}$ (manfaat produk) & 0,774 \\
& $\mathrm{X}_{6}$ (rasa aman) & 0,750 \\
\hline $\mathrm{F}_{3}$ & $\mathrm{X}_{10}$ (promosi) & 0,692 \\
(Ragam Produk) & $\mathrm{X}_{15}$ (banyaknya macam produk) & 0,517 \\
& $\mathrm{X}_{16}$ (fasilitas tambahan) & 0,589 \\
\hline $\mathrm{F}_{4}$ & $\mathrm{X}_{2}$ (pelayanan) & 0,615 \\
(Layanan) & $\mathrm{X}_{7}$ (keluwesan waktu) & 0,554 \\
\hline $\mathrm{F}_{5}$ & $\mathrm{X}_{17}$ (besarnya pendapatan selain gaji) & 0,682 \\
\hline (Pendapatan) & $\mathrm{X}_{3}$ (pendapatan) & 0,537 \\
\hline
\end{tabular}

Tabel diatas menunjukkan factor loading masing-masing variabel lebih besar dari 0,5 sehingga diperoleh komposisi yang lebih baik. Seluruh variabel yang ada terdistribusi cukup rata ke lima faktor yang terbentuk.

Berdasarkan uji hipotesis yang mengatakan bahwa faktor-faktor yang terdiri dari pengalaman perusahaan, manfaat produk, macam ragam produk, layanan dan pendapatan merupakan faktor-faktor yang perlu dipertimbangkan dalam melakukan segmentasi pasar bagi nasabah asuransi di Malang berdasarkan benefit dan preferensi maka bisa disimpulkan disini bahwa hipotesis yang diuji diterima atau hipotesis yang diajukan teruji kebenarannya.

\section{PEMBAHASAN}

Ketepatan pengujian hipotesis mengenai variabel-variabel penelitian sangat tergantung pada kualitas data yang dipakai dalam analisis data untuk pengujian hipotesis tersebut. Data penelitian yang didalam proses pengumpulannya menuntut biaya, waktu, dan tenaga yang besar, menjadi tidak akan berguna bila instrumen penelitian yang digunakan untuk mengumpulkan data penelitian tersebut tidak memiliki validitas dan reliabilitas yang tinggi. 
Didalam analisis faktor variabel $\mathrm{X}_{1}$ (pilihan konsumen untuk berasuransi) tidak ikut dianalisis karena variabel $\mathrm{X}_{1}$ sudah merupakan segmen yang dituju oleh perusahaan asuransi jadi bukan merupakan faktor yang mempengaruhi konsumen dalam mengambil keputusan untuk menjadi nasabah. Sehingga yang dianalisis dalam analisis faktor hanya 16 variabel. Dari hasil pembahasan diperoleh bahwa $\mathrm{X}_{8}$ (pengaruh orang lain) memiliki nilai MSA lebih kecil 0,5 sehingga $\mathrm{X}_{8}$ (pengaruh orang lain) dikeluarkan dari analisis sehingga variabel yang akan dianalisis lebih lanjut hanya 15 variabel saja, untuk mengetahui variabel-variabel standar dari masing-masing faktor, dilakukan rotasi faktor yaitu hasil matriks besaran koefisien antara faktor dengan variabel (loading). Hasil reduksi dari 15 variabel dikelompokkan ke dalam lima faktor.

Sehingga dapat diinterpretasikan bahwa terdapat lima dimensi atau faktor yang dipertimbangkan nasabah asuransi dalam mengambil keputusan untuk menjadi nasabah. Faktor Pengalaman perusahaan, meliputi variabel-variabel $\mathrm{X}_{9}$ (pengalaman perusahaan), $\mathrm{X}_{11}$ (bonafiditas), $\mathrm{X}_{12}$ (kecepatan pembayaran klaim asuransi), $\mathrm{X}_{14}$ (pengaruh personal selling) $\mathrm{X}_{13}$ (ketepatan waktu pembayaran klaim asuransi). Pengalaman dari perusahaan asuransi merupakan pertimbangan utama konsumen dalam mengambil keputusan untuk menjadi nasabah. Dapat dijelaskan bahwa konsumen mempunyai anggapan kuat bahwa pengalaman dalam mengelola asuransi yang baik dari perusahaan akan membuat konsumen/nasabah loyal terhadap perusahaan tersebut. Berdasarkan hal tersebut maka layaklah bagi perusahaan asuransi untuk menginformasikan kepada khalayak serta bisa dijadikan bahan dalam mempromosikan perusahaan dan produk-produknya kepada nasabah dan calon nasabahnya.

Faktor manfaat produk, terdiri dari tiga item yaitu : $\mathrm{X}_{4}$ (tingkat pengembalian investasi), $\mathrm{X}_{5}$ (manfaat produk), $\mathrm{X}_{6}$ (rasa aman). Ketiga item ini diinterpretasikan sebagai upaya perusahaan untuk memperkenalkan asuransi kepada masyarakat terutama nasabah potensial serta mempengaruhi mereka untuk menjadi nasabah pada perusahaan asuransi. Dari hasil penelitian ternyata yang paling mempengaruhi konsumen untuk menjadi nasabah pada perusahaan asuransi adalah pada variabel tingkat pengembalian investasi. Hal ini terjadi karena setiap orang dalam menanamkan uangnya dalam bentuk asuransi mereka akan berpikiran berapakan uang yang akan merka terima pada masa akan datang. Begitu juga tentang manfaat dari berasuransi bagi kepentingan nasabah dimasa akan datang, keterlibatan mereka akan sangat intens sekali mengingat dana yang 
ditanamkan dalam asuransi biasanya cukup besar dan juga berpengaruh sekali pada pendapatan nasabah.

Faktor ragam produk, terdiri dari tiga item yaitu : $\mathrm{X}_{10}$ (promosi), $\mathrm{X}_{15}$ (banyaknya ragam produk), $\mathrm{X}_{16}$ (fasilitas tambahan). Dari hasil penelitian diperoleh bahwa perbedaan macam ragam produk yang ditawarkan oleh perusahaan asuransi relatif beragam dibandingkan dengan perusahaan asuransi, hal ini menjadi pertimbangan utama bagi nasabah perusahaan asuransi. Dapat dijelaskan bahwa konsumen mempunyai anggapan banyaknya macam ragam produk yang ditawarkan oleh perusahaan asuransi menandakan pengalaman dan bonafiditas perusahaan asuransi tersebut bisa diandalkan. Hal ini bisa menjadikan nasabah untuk tidak ragu lagi untuk menanamkan dananya pada perusahaan asuransi sebagai pilihan untuk bersuransi.

Faktor layanan, yang terdiri dari dua item yaitu $\mathrm{X}_{2}$ (pelayanan) dan $\mathrm{X}_{7}$ (keluwesan waktu). Karena layanan perusahaan asuransi merupakan pertimbangan bagi nasabah untuk memutuskan menjadi nasabah pada perusahaan asuransi, maka faktor layanan menjadi pertimbangan terakhir bagi nasabah perusahaan asuransi didalam memutuskan untuk menjadi nasabah.

Faktor pendapatan, yang terdiri dari dua item yaitu $\mathrm{X}_{17}$ (pendapatan lain-lain selaian gaji bulanan) dan $\mathrm{X}_{3}$ (pendapatan). Faktor kelima ini juga menjadi pertimbangan bagi nasabah perusahaan asuransi di dalam mengambil keputusan untuk menjadi nasabah. Pendapatan dapat mempengaruhi seseorang untuk memilih perusahaan tempat dimana untuk mereka akan berasuransi.

\section{KESIMPULAN DAN SARAN}

Kesimpulan

Terdapat lima dimensi atau faktor yang menjadi pertimbangan dalam melakukan segmentasi berdasarkan pendekatan benefit dan preferensi nasabah asuransi di Malang, yaitu : faktor pengalaman perusahaan, faktor manfaat produk, faktor ragam produk, faktor layanan, dan faktor pendapatan. Variabel yang memiliki nilai loading tertinggi dibandingkan variabel-variabel yang lain dalam faktor yang sama berdasarkan nilai loading tertinggi pada masing-masing faktor adalah kecepatan pembayaran uang klaim asuransi di dalam melayani nasabah, variabel ini dikelompokkan ke dalam faktor pengalaman perusahaan yang mempengaruh paling dominan terhadap keputusan 
membeli. Tingkat pengembalian investasi, variabel ini dikelompokkan ke dalam Faktor manfaat produk.

Promosi, hal ini merupakan informasi yang sangat membantu nasabah di dalam mengetahui macam ragam produk yang ditawarkan asuransi. Variabel ini dikelompokkan ke dalam Faktor tiga yaitu Faktor ragam produk. Pelayanan yang diberikan oleh perusahaan bagi nasabah. Variabel ini di kelompokkan ke dalam Faktor layanan. Pendapatan lain-lain selain gaji bulanan, variabel ini dikelompokkan ke dalam Faktor pendapatan.

\section{Saran}

Berdasarkan penelitian yang telah dilakukan, berikut adalah saran dan implementasi bagi perusahaan untuk dapat menyusun strategi dan program-program pemasaran yang tepat agar mempertahankan bisnisnya dan memenangkan persaingan, yaitu :

Perusahaan asuransi sebaiknya mempertahankan pola pemasaran yang telah dilakukan selama ini. Kegiatan promosi yang dilakukan hendaknya dapat membentuk posisi yang baik di benak konsumen, dengan cara menginformasikan kemanfaatan produk pada segmen yang telah dimasuki saat ini, karena promosi yang tepat adalah strategi untuk membangun persepsi konsumen terhadap produk perusahaan, dengan catatan bahwa promosi yang dilakukan mempertimbangkan pengalaman dan reputasi perusahaan sehingga harapan konsumen sesuai dengan kenyataan yang ada.

Mengingat sumber pendapatan utama perusahaan asuransi masih tergantung pada jumlah nasbah dan banyaknya polis asuransi yang masuk, maka perusahaan dituntut untuk selalu dapat memberi pelayanan yang lebih pada pelanggannya.

\section{Daftar Rujukan}

Kotler, Philip, 1998, Manajemen Pemasaran, Analisis, Perencanaan, Implementasi dan Kontrol, Alih bahasa Hendra teguh dan Rony A. Rusli, Edisi 9, Jilid 1 dan 2, PT Prenhalindo, Jakarta

Kasali, Rhenald, 1998, Membidik Pasar Indonesia, Segmentasi, Targeting dan Positioning, PT Gramedia Pustaka Utama, Jakarta 
Lamb, Charles W. Hair, Joseph F. McDaniel, Carl. 2001, Pemasaran, Edisi pertama, Penerbit Salemba empat, Jakarta.

Payne, Adrian, 2001, The Essence of Services Marketing Pemasaran Jasa, diterjemahkan oleh Fandi Tjiptono, Edisi kedua, Penerbit ANDI, Yogyakarta.

Sutisna, 2003, Perilaku Konsumen Dan Komunikasi Pemasaran, Cetakan ketiga, Penerbit PT Remaja Rosdakarya, Bandung.

Swastha DH, Basu. 1996, Azas-azas Marketing, Edisi ketiga, Penerbit Liberty, Yogyakarta. 